\title{
The influence of brands on consumer behaviour in conditions of COVID-19 pandemic: Bibliometric and visualization analysis
}

\author{
Liudmyla Saher ${ }^{1,{ }^{* *}}$, Daria Kolesnyk ${ }^{1}$, Liubov Syhyda ${ }^{1}$, Nadiya Fisunenko ${ }^{2}$ \\ ${ }^{1}$ Sumy State University, Department of Marketing, Sumy, Ukraine \\ ${ }^{2}$ Dnepropetrovsk State University of Internal Affairs, Department of Analytical Economics and \\ Management, Dnipro, Ukraine
}

\begin{abstract}
The topic of branding is part of the marketing concept and is actively researched. This study presents a trend analysis, bibliometric overview, and visualization of the current state within the research problem of branding. A review of 1,014 publications from the Scopus database (1996-2020) was conducted. Two combinations of words with a logical operator ("brand" and "consumer behaviour, crisis") were used. VOSviewer was used to visualize the results and graphically display the material. The analysis helped to draw some valuable conclusions. As a result of the analysis, it is determined that: 1) using filters, the total number of publications in the research field of branding is $984 ; 2$ ) the growth of the publication activity occurred after 2009. 3) the largest number of studies is conducted by scientists from Europe, North America, Asia and Australia; 4) until 2014, scientists focused on researching the essence of the brand and branding, its benefits, features, etc., then scientists were more focused on the issues of sustainable development, the role and significance of crisis factors, including the impact of the pandemic; 5) the relationships among keywords within the research topic form the following clusters: marketing, corporate social responsibility, brand equity, consumer behaviour, and consumption behaviour. The obtained results are applicable and can be a guidance for further research in the field of branding.
\end{abstract}

\section{Introduction}

All consumers can be divided into brand lovers and those who avoid brands. But the latter inevitably fall under the influence of other less visible brands. Most people think that brands are something modern, with a famous name and premium goods, financially not available to everyone. But this is not the case any longer.

It is important to remember that brand is not just a complex of logos, colours, and icons. It is a promise, a message to consumers. Therefore, the influence of a brand on consumers and their behaviour is huge. When speaking about the influence of a brand on a consumer, it

\footnotetext{
Corresponding author: 1 sager@ukr.net
} 
is worth remembering that in today's economic situation, branding plays a huge role, since it is a long-term investment. Even the world's most famous brands constantly test new products, improve quality, and in other ways strengthen audience loyalty. To maintain competitiveness, a brand must constantly fight for its audience and overcome all difficulties, including the COVID-19 pandemic.

The topic of branding has become quite relevant for scientists over the past 10 years. The scientists in the papers $[1 ; 2]$ proved the importance of advertising as a part of branding and the role of digital marketing tools in the globalization context.

The problems of a country's and company's image are discussed in the following studies [3-5]. Moreover, the impact of an increasing interest to sustainable development and sustainable entrepreneurship on the green brand formation is shown in the papers [6-10]. Research of economic and social processes as an element of the country's brand are discussed in the following studies [13-17]. The COVID-19 pandemic has made great adjustments in all areas of business and people's lives, including branding and consumers' behaviour [18-21]. The impact of Covid-19 pandemic is discussed in [22-29].

Thus, this article aims to investigate the problem of brand influence on consumer behaviour under various factors, including such a factor as Covid-19 pandemic in-depth based on visualized and bibliometric analysis.

\section{Method}

To achieve the purpose of the research, a bibliometric analysis has been carried out [30-31]. Moreover, there was conducted a visualized analysis [32-106]. The bibliometric analysis in this paper includes six steps and aims to collect data in the area of branding. The logical sequence of the research is the following:

1. Research area: "branding".

2.Information source: Scopus database.

3. Search field: "title, abstract, keywords".

4. Keyword's search: "brand" AND "consumer behaviour, crisis".

5. Language of publications: English.

6. Research years: from 1996 till 2020 (before 1996 there was only one work in 1989).

Thus, for further research 1,014 publications were chosen. Additionally, the importance of branding was confirmed by trend analysis made using Google Trends.

\section{Results and Discussions}

The scientists have begun investigating the problem of branding development, its influence on consumer behaviour relatively recently. The conducted research shows that the topic of branding, its influence on consumer behaviour, and other related aspects have been developing since 1996. The distribution of scientific papers over the years is illustrated in Figure 1.

According to Figure 1, the growth of the publication activity started in 2010 . Since then, there has been a steady trend for increasing the number of publications.

All these publications contain research related to branding, but they are multidirectional and relate to different components of this concept. For better understanding of the essence and interconnectedness of the analysed issues, research clusters have been formed. They help to identify, visualize, and understand the most frequent keywords relevant to the research area (Fig. 2).

Thus, the network visualization between 142 keywords includes 10 clusters. The most powerful cluster (purple) is formed around the concept of "marketing" (the concept 
establishes 72 links, the total link strength is 147), this cluster includes the following main keywords: "social media", "brands", "consumer engagement".

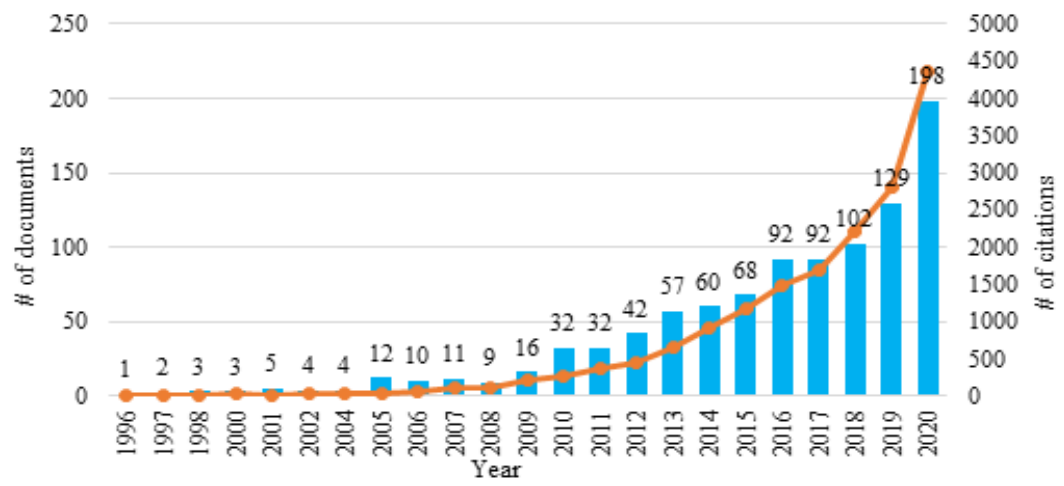

Fig. 1. Dynamics of the publications and citations number in the research field in 1996-2020 (based on the Scopus Database)

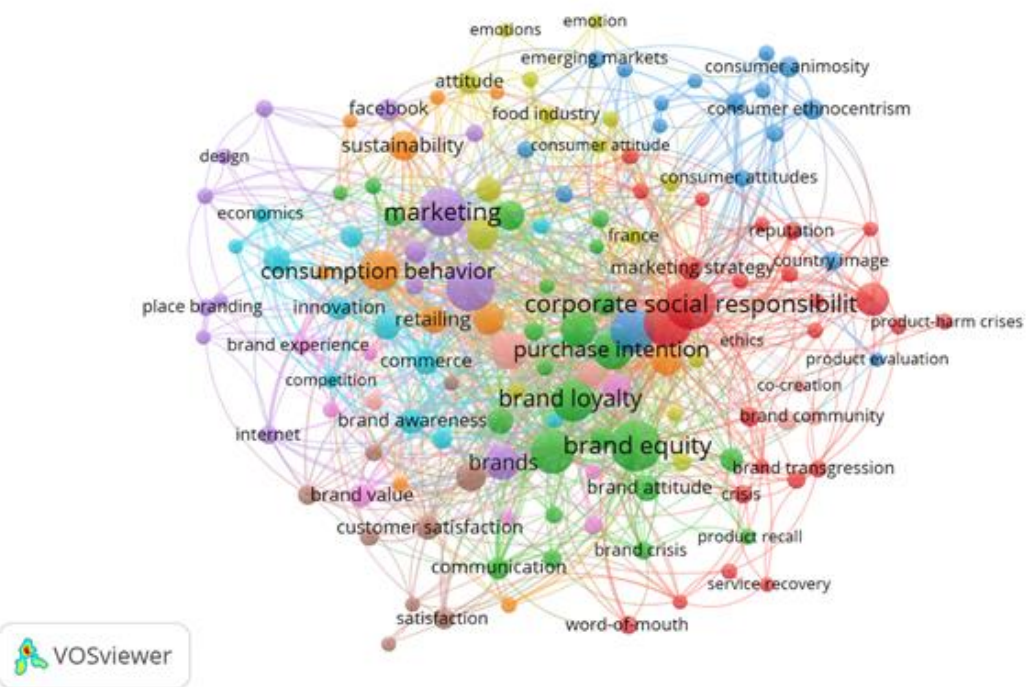

Fig. 2. A visualization map of the relationship among keywords (based on the Scopus Database), generated using VOSviewer

The second (red) cluster is based on the concept of "corporate social responsibility" (59 links, the total link strength is 104), and includes the keywords: "consumer behaviour", "marketing strategy", "country of origin", "reputation". The third (green) cluster covers such keywords as "brand loyalty", "brand image", "purchase intention", "brand management", and others, and forms around the concept of "brand equity" (establishes 45 links, the total link strength is 88). The fourth (blue) cluster is tied to the concept of "consumer behaviour" (establishes 52 links, the total link strength is 79) and covers the keywords "consumer attitudes", "consumer ethnocentrism", "consumer animosity", "international marketing", "country image". The fifth (orange) cluster is formed around the concept of "consumption behaviour" (establishes 55 links, the total link strength is 114). This cluster includes the keywords "perception", "trust", "sustainability", "retailing".

Table 1 shows the main publishing countries in the research area. 
According to Table 1, the topic of branding, its changes under the influence of the pandemic and other crisis situations were covered by scholars from Europe (United Kingdom, France, Spain, Germany, Italy) - 301 publications; North America (the USA, Canada) - 354 publications; Asia (China, India) - 117 publications, and Australia 84 publications. The CIS countries have not yet begun studying this area actively.

Table 1. Countries with the largest number of publications in the research area in the period from 1996 to 2020 (based on the Scopus database)

\begin{tabular}{|l|c|c|}
\hline Country & Number of publications & Number of citations \\
\hline The United States & 260 & 5,267 \\
\hline The United Kingdom & 135 & 2,726 \\
\hline Australia & 84 & 1,822 \\
\hline France & 71 & 2,272 \\
\hline India & 61 & 317 \\
\hline Spain & 59 & 1,026 \\
\hline China & 56 & 585 \\
\hline Germany & 46 & 635 \\
\hline Italy & 43 & 510 \\
\hline Canada & 41 & 1,432 \\
\hline
\end{tabular}

Using VOSviewer, ten country clusters were formed (Fig. 3).

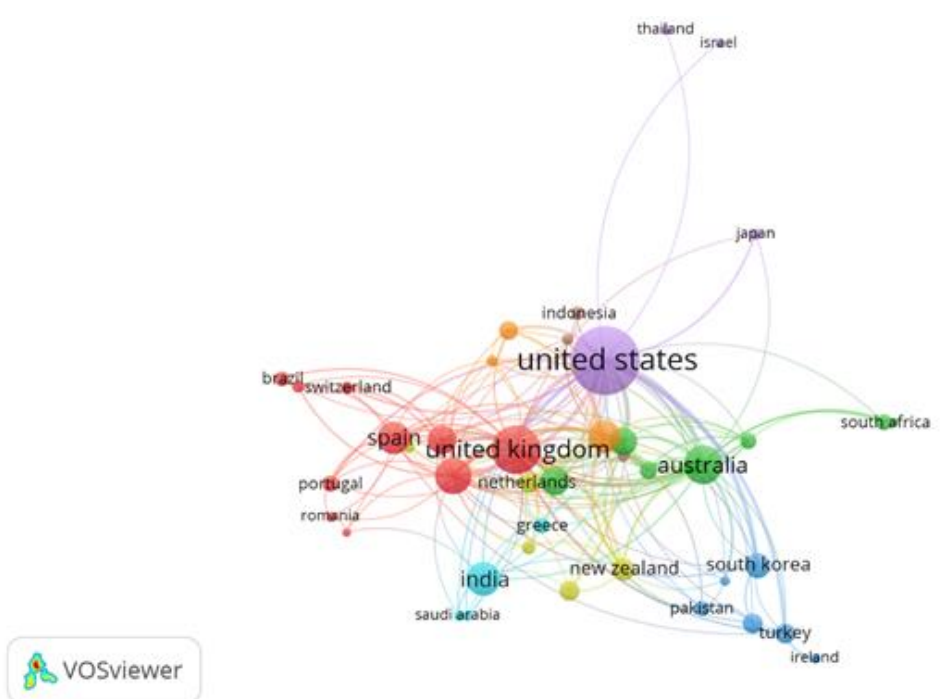

Fig. 3. The network of relationships among countries in the research area in 1996-2020, based on the Scopus Database (generated using VOSviewer)

Four countries have the leading positions in this area. These are the USA (260 documents, 5267 citations), the United Kingdom (135 documents, 2726 citations), Australia (84 documents, 1822 citations), and France ( 71 documents, 2272 citations). These four countries form the main clusters, and they are followed by India (61 documents, 317 citations) and Spain (59 documents, 1026 citations). Other clusters are smaller.

The most cited article, with 659 citations, is "Corporate Social Responsibility and Consumers' Attributions and Brand Evaluations in a Product-Harm Crisis", written by Klein, J. and Dawar, N. [107]. This study shows the role of corporate social responsibility in 
consumers' evaluation of brands and goods along with economic or "rational" motives (for example, product attributes).

The article by Andreasen, A.R. "Marketing Social Marketing in the Social Change Marketplace" [108] goes second. It has been cited 453 times. The article shows that social marketing faces significant barriers to growth because there is no clear understanding of what the field is and what its role should be in relation to other approaches to social change. The author proposes a specific social marketing branding campaign to advance the field, with roles for academics and the American Marketing Association.

Table 2. The 10 most cited studies in the research area in the period from 1996 to 2020 (based on Scopus Database)

\begin{tabular}{|c|c|c|c|}
\hline $\begin{array}{c}\text { Total } \\
\text { citations }\end{array}$ & Author & Article title & $\begin{array}{c}\text { Journal/Year of } \\
\text { publication }\end{array}$ \\
\hline 659 & $\begin{array}{c}\text { Klein, J., } \\
\text { Dawar, N. [107] }\end{array}$ & $\begin{array}{l}\text { Corporate social responsibility and } \\
\text { consumers' attributions and brand } \\
\text { evaluations in a product-harm crisis }\end{array}$ & $\begin{array}{l}\text { International Journal } \\
\text { of Research in } \\
\text { Marketing, } 2004\end{array}$ \\
\hline 453 & $\begin{array}{l}\text { Andreasen, A.R. } \\
{[108]}\end{array}$ & $\begin{array}{c}\text { Marketing social marketing in the social } \\
\text { change marketplace }\end{array}$ & $\begin{array}{l}\text { Journal of Public } \\
\text { Policy and } \\
\text { Marketing, 2002 }\end{array}$ \\
\hline 271 & $\begin{array}{c}\text { Geuens, M., } \\
\text { Weijters, B., } \\
\text { De Wulf, K. [109] }\end{array}$ & A new measure of brand personality & $\begin{array}{c}\text { International Journal } \\
\text { of Research in } \\
\text { Marketing, 2009 }\end{array}$ \\
\hline 231 & Greenberg, M. [110] & $\begin{array}{l}\text { Branding New York: How a city in crisis } \\
\text { was sold to the world }\end{array}$ & $\begin{array}{l}\text { Branding New York: } \\
\text { How a City in Crisis } \\
\text { Was Sold to the } \\
\text { World, } 2008\end{array}$ \\
\hline 224 & Sharma, P. [111] & $\begin{array}{l}\text { Country of origin effects in developed and } \\
\text { emerging markets: Exploring the } \\
\text { contrasting roles of materialism and value } \\
\text { consciousness }\end{array}$ & $\begin{array}{c}\text { Journal of } \\
\text { International } \\
\text { Business Studies, } \\
2011 \\
\end{array}$ \\
\hline 219 & He, H., Li, Y. [112] & $\begin{array}{l}\text { CSR and Service Brand: The Mediating } \\
\text { Effect of Brand Identification and } \\
\text { Moderating Effect of Service Quality }\end{array}$ & $\begin{array}{l}\text { Journal of Business } \\
\text { Ethics, } 2011\end{array}$ \\
\hline 216 & Williams, A. [113] & $\begin{array}{l}\text { Tourism and hospitality marketing: } \\
\text { Fantasy, feeling and fun }\end{array}$ & $\begin{array}{c}\text { International Journal } \\
\text { of Contemporary } \\
\text { Hospitality } \\
\text { Management, 2006 }\end{array}$ \\
\hline 201 & $\begin{array}{l}\text { van Noort, G., } \\
\text { Willemsen, L.M. } \\
{[114]}\end{array}$ & $\begin{array}{l}\text { Online Damage Control: The Effects of } \\
\text { Proactive Versus Reactive Webcare } \\
\text { Interventions in Consumer-generated and } \\
\text { Brand-generated Platforms }\end{array}$ & $\begin{array}{l}\text { Journal of Interactive } \\
\text { Marketing, } 2012\end{array}$ \\
\hline 201 & $\begin{array}{l}\text { Kayaman, R., } \\
\text { Arasli, H. [115] }\end{array}$ & $\begin{array}{l}\text { Customer based brand equity: Evidence } \\
\text { from the hotel industry }\end{array}$ & $\begin{array}{l}\text { Managing Service } \\
\text { Quality, } 2007\end{array}$ \\
\hline 192 & $\begin{array}{c}\text { Pollay, R.W., } \\
\text { Siddarth, S., } \\
\text { Siegel, M., (...), } \\
\text { Giovino, G.A., } \\
\text { Eriksen, M.P. [116] }\end{array}$ & $\begin{array}{l}\text { The last straw? Cigarette advertising and } \\
\text { realized market shares among youths and } \\
\text { adults, 1979-1993 }\end{array}$ & $\begin{array}{c}\text { Journal of Marketing, } \\
1996\end{array}$ \\
\hline
\end{tabular}

And the third place is taken by the study by Geuens, M., Weijters, B., De Wulf, K. "A New Measure of Brand Personality" [109] with 271 citations. In this study, the authors developed a new brand personality measure consisting of personality items only. 12,789 Belgian respondents participated in a study on 193 brands. The new scale consisted of five 
factors that showed an affinity with the Big Five of human personality and cross-cultural validity (in the US and nine other European countries).

Examining the column "year of publication", there can be observed a tendency to interest increasing and deepen into the topic of the branding. Publications cover not only components of the brand but also its impact on the consumer, and various areas of marketing.

Figure 4 characterizes a scientific interest in the research area. The research period is from March 1996 to 2020. By 2014, scientists were more focused on analysing the essence of the brand, its features, brand varieties, etc. In subsequent years, scientists were more focused on issues of sustainable development, the role, and significance of crisis factors, including the impact of the pandemic. The same colour means that nodes and keywords belong to the same cluster. The most common keywords leading the main clusters are "marketing" (50 links), "corporate social responsibility" (56 links), "brand equity" (56 links), "consumer behaviour" (44 links), "consumption behaviour" (36 links).

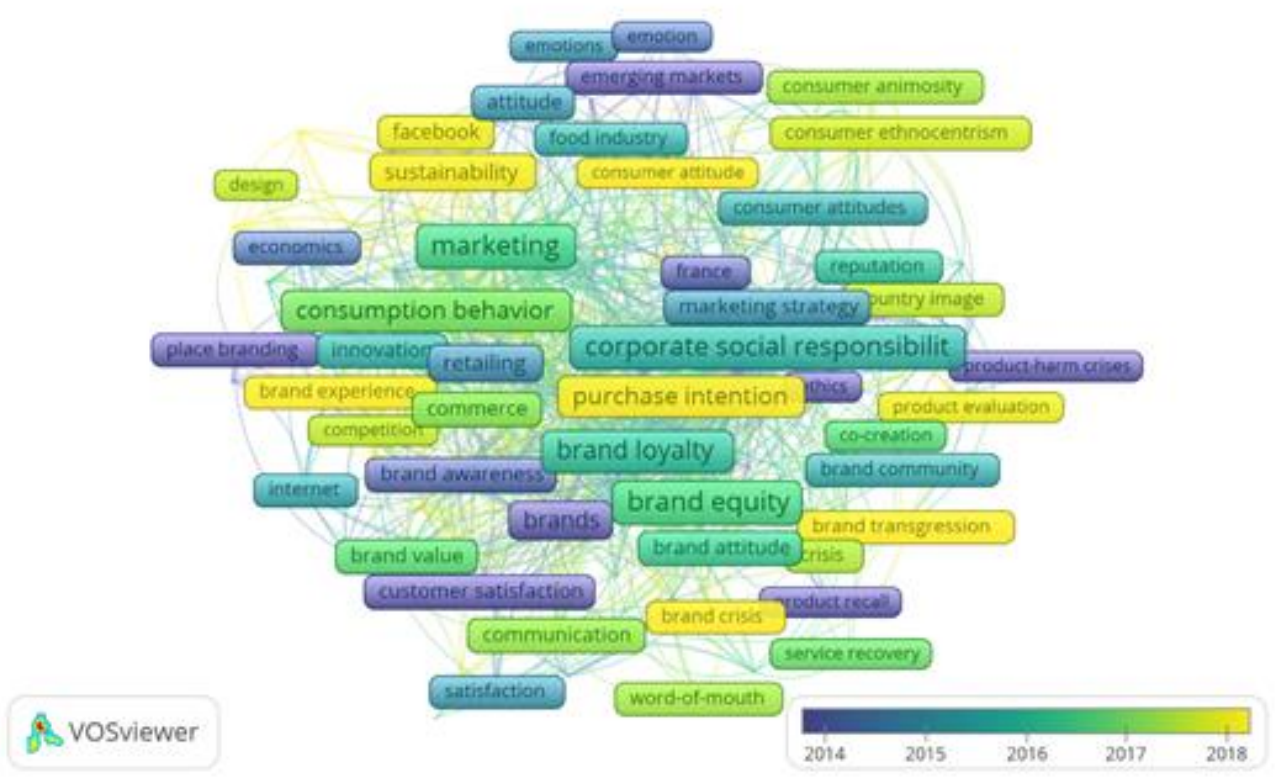

Fig. 4. The scientific interest on the topic of brand from 1996 to 2020 (based on the Scopus database)

Considering the above, there can be expected further development of the research area. Since the horizons expand with each publication, the authors describe new problems and aspects. The brand idea is alive and can be viewed from different angles and applying various scientific criteria.

From the studies carried out above, it can be seen that not all consumers are willing to overpay for a brand. The average person is looking for great deals, promotions, discounts to save money, postpone payments, or pay for the necessary fees. To prove it, there has been investigated the dynamics of the search request of popular brands using Google Trends (Fig. 5-9). 


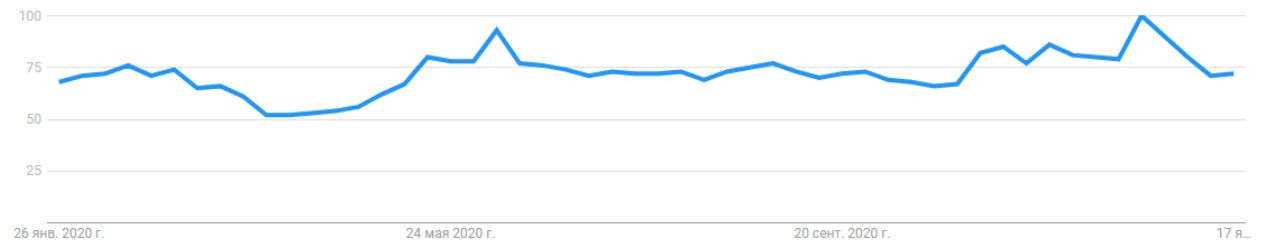

Fig. 5. The dynamics of the popularity of Starbucks request around the world

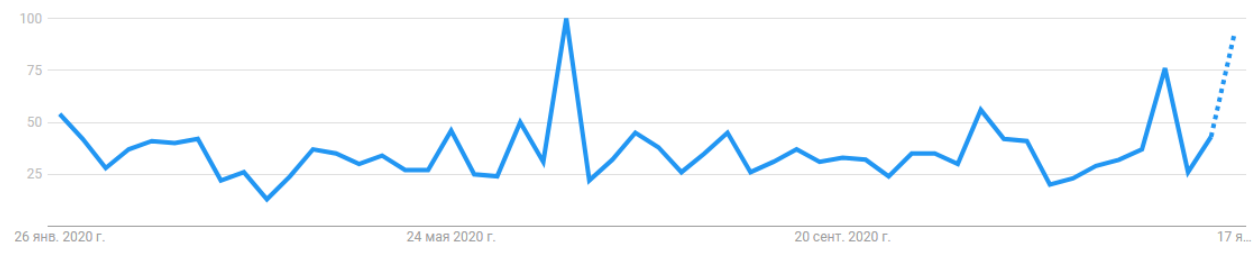

Fig. 6. Dynamics of the popularity of the Starbucks request in Ukraine

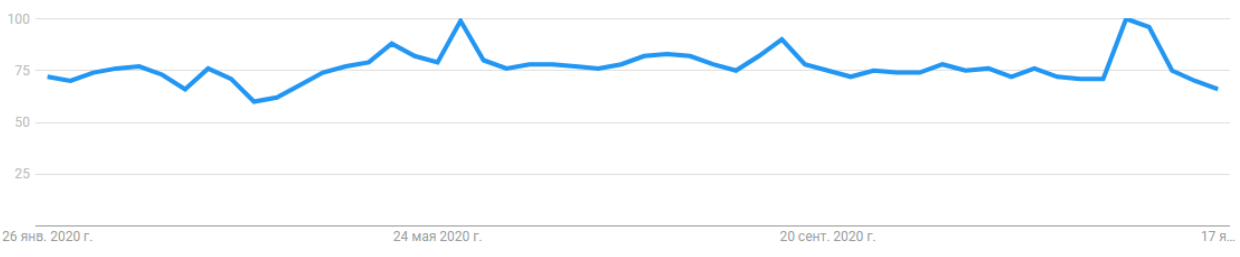

Fig. 7. The dynamics of the popularity of McDonald`s request around the world

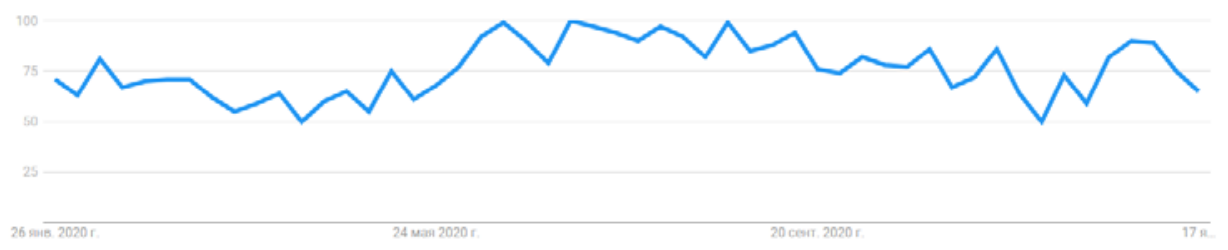

Fig. 8. Dynamics of the popularity of the McDonald`s request in Ukraine 


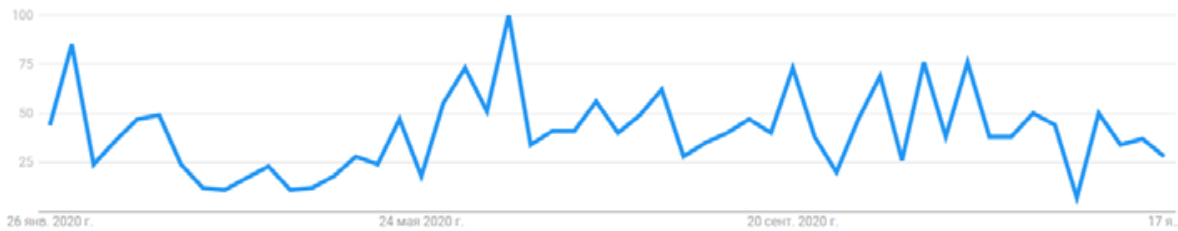

Fig. 9. Dynamics of the popularity of the Aroma Kava request in Ukraine region

According to the Google Trends indicators, there is confirmed the argument that brands need to be within consumers' reach to have a quality impact on them. Thus, the number of Starbucks requests around the world in 2020 is stable and at a higher level than the same request in Ukraine. On the contrary, for McDonald's network in Ukraine and around the world the requests are almost the same. In the case of Aroma Kava, there are no inquiries "all over the world", because the consumers simply do not know about the brand.

Also, the popularity of brands during the pandemic remains an exciting issue. During the COVID-19 pandemic, to stay afloat manufacturers had to react quickly. One of the best options was switching to e-commerce. Another similar option was the development of mobile applications. For the food business, the introduction of a courier delivery service was good salvation. This has become a benefit. Figures 10-11 show how the query statistics for «delivery» request and «buy online» request have changed over the past 5 years in Ukraine.

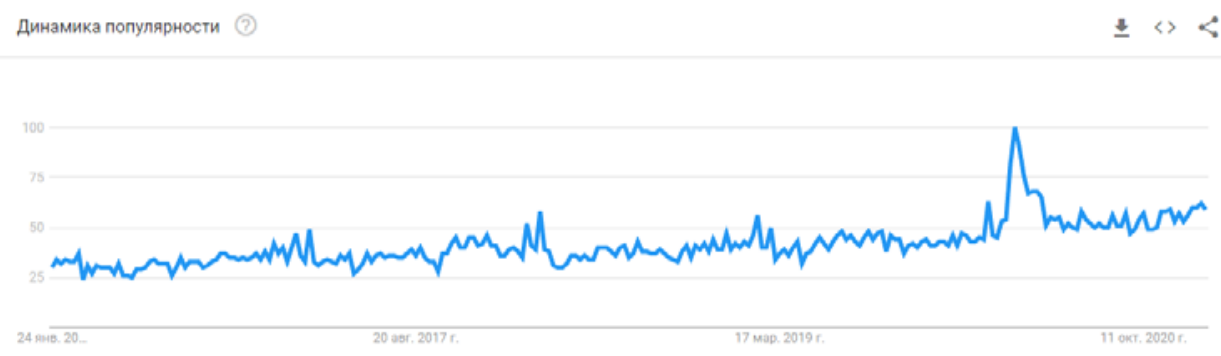

Fig. 10. Dynamics of the popularity of the «delivery» request in Ukraine

Delivery request in Ukraine became popular at the end of 2019. The peak of the delivery request was at the end of March 2020 (during the lockdown period). However, the graph tends to increase. The reason is that brands with a delivery service and the delivery companies themselves become more popular, at least until the end of the pandemic.
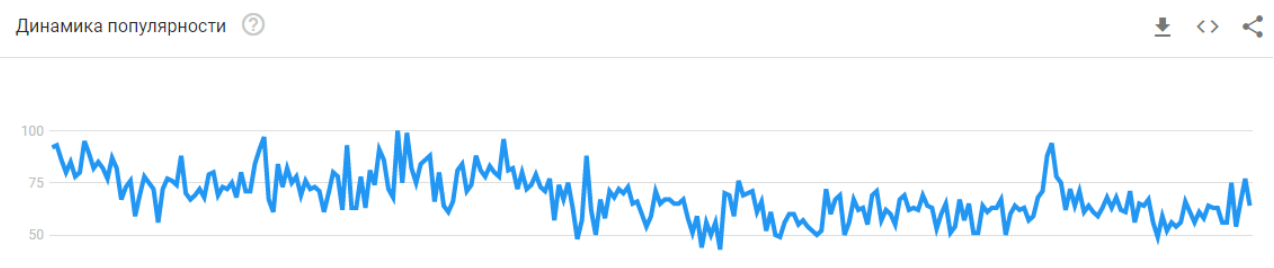

Fig. 11. Dynamics of the popularity of the «buy online» request in Ukraine 
The request "buy online" was popular even before the Covid-19 pandemic. Moreover, since the quarantine began, the requests for online buys increased. Consumers actively searched for goods and services online at the end of March 2020, and in January 2021. The explanation is that the consumers could not buy certain groups of goods in physical stores. So, brands must monitor their sites, keep up with the life rhythm not to lose potential consumers.

Besides, according to the Serpstat results (Fig. 12), the number of visitors of Rozetka.ua site per day was quite stable until mid-2018 (for about 6 million people). At the end of 2019, there were 8 million visitors per day. In 2020 there were 15-30 million visitors and in midJanuary 2021 - 31.5 million visitors per day.

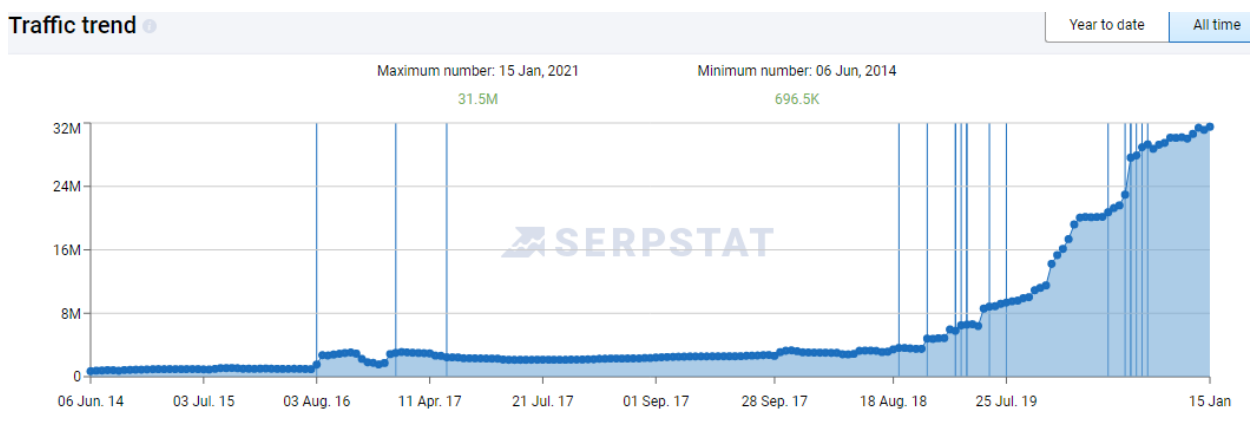

Fig. 12. Site traffic data Rozetka.ua from Serpstat free version

The "customer journey" shows the path from the need manifestation to its satisfaction (Fig. 13). Normally, the average consumer can easily switch between branded products and those they see for the first time. Brands reach their audience usually with distinctive qualities: a sign of luxury, good quality, trust in the manufacturer, service, and other characteristics.
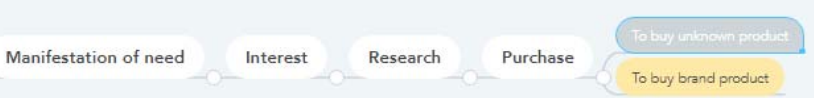

The origin of the need

Fig. 13. Customer journey (made with mindmeisret.com)

But during a pandemic, the issues escalate. The financial situation becomes difficult. The cost of branded items can be higher than the cost of non-branded ones. Additionally, during the quarantine 2020, many small entrepreneurs appeared on the market. Mainly they sell products through various sites on the Internet. Therefore, if the brand representatives in marketing and sales departments do not deal with this issue in time, there is a risk of losing customers in the future.

\section{Conclusions}

Several conclusions can be made from this study. First, brands have an impact on consumer behaviour. They build loyalty, trust, and long-term market relationships with consumers. Although the research topic has not been investigated enough in recent years, attention to 
branding and consumer attitudes is growing. Scientists from the USA and Great Britain show the highest publication activity in the research topic. Their works are actively cited and scientists rely on them to write new research. Mostly, the concept of "brand" is considered together with "marketing", "corporate social responsibility", "brand equity", and "consumer behaviour".

Second, brands need to be in the same location as the consumers for larger audience coverage. Otherwise, it can cause the decreasing interest of potential consumers. Thus, brands limit themselves in reach, profit, distribution, and other performance indicators.

Third, brands must stay on top, especially during the COVID-19 pandemic. Quarantine in all countries of the world takes its toll of all spheres of people's lives. Due to periodic lockdowns, bans on mass events, restrictions in public places, and innovations to maintain sanitary conditions, some brands can simply disappear due to unprofitability.

Therefore, all brands are looking for the ways to be competitive. Some brands add a delivery function of goods. Others brands start online stores. All these can help brands to preserve their popularity.

\section{References}

1. N. Letunovska, L. Saher, T. Vasylieva, S. Lieonov. Paper presented at the E3S Web of Conferences, 250 (2021).

2. A. Teletov, S. Teletova, N. Letunovska. Periodicals of Engineering and Natural Sciences, 7, 2, 458-465 (2019).

3. O. Petroye, O. Lyulyov, I. Lytvynchuk, Y. Paida, V. Pakhomov. International Journal of Safety and Security Engineering, 10(4), 459-466 (2020).

4. H. Dzwigol, M. Dźwigoł-Barosz, A. Kwilinski, International Journal of Entrepreneurship, 24(1), 1-5 (2020)

5. J. Cebula, O. Chygryn, S. Chayen, V., T. Pimonenko. International Journal of Environmental Technology and Management, 21(5-6), 421-438 (2018). doi:10.1504/IJETM.2018.100592

6. O. Lyulyov, T. Pimonenko, A. Kwilinski, H. Dzwigol, M. Dzwigol-Barosz, V. Pavlyk, P. Barosz, Energies, 14(2) 373 (2021)

7. O. Chigrin, T. Pimonenko. International Journal of Ecology and Development, 29(3), 1-13 (2014)

8. Y. Petrushenko, A. Vadym, A. Vorontsova, O. Ponomarenko. in Proceedings of the E3S Web of Conferences, 202 (2020).

9. A. Kwilinski, O. Vyshnevskyi, H. Dzwigol, Journal of Risk and Financial Management, 13(7), 142 (2020)

10. N. Stukalo, M. Lytvyn, Y. Petrushenko, Y. Omelchenko, The achievement of the country's sustainable development in the conditions of global threats, in Proceedings of the E3S Web of Conferences, 211 (2020).

11. A. Kwilinski, H. Dzwigol, V. Dementyev, International Journal of Entrepreneurship, 24(1 Special Issue), 1-5 (2020)

12. O. Chygryn, Y. Bilan, A. Kwilinski, Marketing and Management of Innovations, 3, 356-368 (2020)

13. T. Vasilyeva, O. Kuzmenko, V. Bozhenko, O. Kolotilina. in Proceedings of CEUR Workshop Proceedings, 2422, 134-146 (2019).

14. H. Dzwigol, M. Dzwigol-Barosz, Z. Zhyvko, R. Miskiewicz, H. Pushak, Journal of Security and Sustainability Issues, 8(3), 307-317 (2019)

15. H. Dzwigol, M. Dzwigol-Barosz, Academy of Strategic Management Journal, 19(5), 1$7(2020)$ 
16. I. Didenko, K. Volik, T. Vasylieva, S. Lyeonov, N.Antoniuk. in Proceedings of the E3S Web of Conferences, 202 (2020).

17. I. Didenko, K. Volik, T. Vasylieva, S. Lyeonov, N. Antoniuk. in Proceedings of the E3S Web of Conferences, 234 (2021)

18. I. Didenko, J. Paucz-Olszewska, S. Lyeonov, A. Ostrowska-Dankiewicz, Z. Ciekanowski. Journal of International Studies, 13(2), 347-359 (2020).

19. J. Tsalikis, B. Seaton. Business Ethics and Leadership, 4(2), 6-15 (2020).

20. M. Neger, Md. Z. H. Bhuiyan, Md. H. K.Chowdhury, A. Hossain. Business Ethics and Leadership, 3(2), 72-82 (2019).

21. A. Hossain, Md. L. Rahman, Md. M. Hasan. Business Ethics and Leadership, 2(4), 7482 (2018).

22. V. Smiianov, O. Lyulyov, T. Pimonenko, T. Andrushchenko, S. Sova, N. Grechkovskaya. Wiadomosci Lekarskie, 73(11), 2332-2338 (2020).

23. F. Rahmanov, R. Aliyeva, A. Rosokhata, N. Letunovska. Marketing and Management of Innovations, 3, 195-207 (2020).

24. O. Kuzmenko, T. Vasylieva, S. Vojtovič, O. Chygryn, V.Snieška. Economics and Sociology, 13(4), 318-340 (2020).

25. V. A. Smiianov, T. A. Vasilyeva, O. Y. Chygryn, P. M. Rubanov, T. M. Mayboroda, Wiadomosci Lekarskie, 73(10), 2181-2187 (2020).

26. P. Dutta, U. Dutta, S. Hasan, S. Sarkar, T. Sana. SocioEconomic Challenges, 4(3), 93$103(2020)$.

27. B.S. Lopez, A.V. Alcaide. Blockchain. SocioEconomic Challenges, 4(2), 78-89 (2020).

28. G. Keliuotytè-Staniulènienè, K. Daunaravičiūtè. Financial Markets, Institutions and Risks, 5(1), 50-60 (2021).

29. F. D. Tommaso. Financial Markets, Institutions and Risks, 4(4), 91-108 (2020).

30. M. Soliman, O. Lyulyov, H. Shvindina, R. Figueiredo, T. Pimonenko. European Journal of Tourism Research, 28 (2021)

31. I. Vakulenko, L. Saher, O. Lyulyov, T. Pimonenko. in Proceedings of E3S Web of Conferences, 250 (2021)

32. Y. Kharazishvili, A. Kwilinski, O. Grishnova, H. Dzwigol, Sustainability, 12(21), 8953 (2020)

33. H. Dzwigol, Marketing and Management of Innovation, 1, 324-335 (2021)

34. R. Miskiewicz, Energies, 13(22), 6106 (2020)

35. N. Letunovska, O. Lyuolyov, T. Pimonenko, V. Aleksandrov. in Proceedings of the E3S Web of Conferences, , 234. doi:10.1051/e3sconf/202123400008.

36. S. Cyfert, A. Chwiłkowska-Kubala, W. Szumowski, R. Miśkiewicz, PLoS ONE, 16(4), e0249724 (2021)

37. B. Czyżewski, A. Matuszczak, R. Miskiewicz, Technological and Economic Development of Economy, 25(1), 82-102 (2019)

38. H. Dzwigol, M. Dzwigol-Barosz, R. Miskiewicz, A. Kwilinski, Entrepreneurship and Sustainability Issues, 7(4), 2630-2644 (2020)

39. E. Gross-Golacka, M. Kusterka-Jefmanska, R. Miskiewicz, B. Jefmanski, A. Rzepka, T. Kupczyk, European Research Studies Journal, XXIV(2B), 410-429 (2021)

40. L. Hrytsenko, I. Boiarko, O. Tverezovska, J. Polcyn, R. Miskiewicz, Marketing and Management of Innovations, 2, 155-165 (2021)

41. R. Miskiewicz, Polityka Energetyczna, 21(2), 49-62 (2018)

42. R. Miskiewicz, Virtual Economics, 2(2), 37-47 (2019)

43. R. Miskiewicz, Marketing and Management of Innovations, 3, 371-381 (2020)

44. R. Miśkiewicz, Journal of Risk and Financial Management, 14(2), 59 (2021)

45. R. Miśkiewicz, R. Wolniak, Sustainability, 12(14), 5776 (2020) 
46. O. Prokopenko, R. Miskiewicz, Entrepreneurship and Sustainability Issues, 8(2), 269$284(2020)$

47. A. Rzepka, R. Borowiecki, R. Miskiewicz, Z. Olesinski, European Research Studies Journal, XXIV(2), 1149-1162 (2021)

48. P.W. Saługa, K. Szczepańska-Woszczyna, R. Miśkiewicz, M. Chłąd, Energies, 13(18), $4833(2020)$

49. H. Dźwigoł, Virtual Economics, 4(1), 98-117 (2021)

50. H. Dzwigol, Marketing and Management of Innovations, 1, 128-135 (2020)

51. H. Dzwigol, Academy of Strategic Management Journal, 19(4), 1-8 (2020)

52. H. Dzwigol, R. Wolniak, Przemysl Chemiczny, 97(7), 1114-1116 (2018)

53. H. Dzwigol, S. Shcherbak, M. Semikina, O. Vinichenko, V. Vasiuta, Academy of Strategic Management Journal, 18(SI1), 1-8 (2019)

54. H. Dzwigol, O. Aleinikova, Y. Umanska, N. Shmygol, Y. Pushak, Journal of Entrepreneurship Education, 22(1S), 1-7 (2019)

55. Y. Kharazishvili, A. Kwilinski, O. Sukhodolia, H. Dzwigol, D. Bobro, J. Kotowicz, Energies, 14(8), 2126 (2021)

56. Y. Kharazishvili, A. Kwilinski, H. Dzwigol, V. Liashenko, Virtual Economics, 4(2), 7$40(2021)$

57. O. Lyulyov, I. Vakulenko, T. Pimonenko, A. Kwilinski, H. Dzwigol, M. DzwigolBarosz, Energies, 14(12), 3497 (2021)

58. H. Dzwigol, M. Dźwigoł-Barosz, Financial and Credit Activity: Problems of Theory and Practice, 2(25), 424-437 (2018)

59. O. Arefieva, O. Polous, S. Arefiev, V. Tytykalo, A. Kwilinski, IOP Conference Series: Earth and Environmental Science, 628, 012039 (2021)

60. V. Boiko, A. Kwilinski, M. Misiuk, L. Boiko, Economic Annals-XXI, 175(1-2), 68-72 (2019)

61. S. Bogachov, A. Kwilinski, B. Miethlich, V. Bartosova, A. Gurnak, Entrepreneurship and Sustainability Issues, 8(2), 487-499 (2020)

62. N. Dalevska, V. Khobta, A. Kwilinski, S. Kravchenko, Entrepreneurship and Sustainability Issues, 6(4), 1839-1860 (2019)

63. V.V. Dementyev, A. Kwilinski, Journal of Institutional Studies, 12(1), 100-116 (2020)

64. V. Khrapkina, A. Kwilinski, J. Polcyn, K. Pająk, V. Stratonov, V. Kobets, V. Virtual Economics, 4(2), 41-73 (2021)

65. V. Koibichuk, N. Ostrovska, F. Kashiyeva, A. Kwilinski, Marketing and Management of Innovations, 1, 253-265 (2021)

66. V. Kondratenko, O. Okopnyk, L. Ziganto, A. Kwilinski, Marketing and Management of Innovations, 1, 87-94 (2020)

67. A. Kuzior, A. Kwilinski, V. Tkachenko, V. Entrepreneurship and Sustainability, 7(2), 1353-1376 (2019)

68. A. Kuzior, A. Kwilinski, I. Hroznyi, Energies, 14(9), 2572 (2021)

69. A. Kuzior, O. Lyulyov, T. Pimonenko, A. Kwilinski, D. Krawczyk, Sustainability, 13(15), 8145 (2021)

70. A. Kwilinski, Virtual Economics, 1(1), 7-25 (2018)

71. A. Kwilinski, Marketing and Management of Innovations, 4, 116-128 (2018)

72. A. Kwilinski, Academy of Accounting and Financial Studies Journal, 23(SI2), 1-6 (2019)

73. A. Kwilinski, V. Tkachenko, A. Kuzior, Journal of Security and Sustainability Issues, 9(2), 561-570 (2019)

74. A. Kwilinski, N. Dalevska, S. Kravchenko, I. Hroznyi, I. Kovalenko, Journal of Entrepreneurship Education, 22(SI1), 1-7 (2019) 
75. A. Kwilinski, I. Ruzhytskyi, V. Patlachuk, O. Patlachuk, B. Kaminska, Journal of Legal, Ethical and Regulatory Issues, 22(SI2), 1-6 (2019)

76. A. Kwilinski, R. Volynets, I. Berdnik, M. Holovko, P. Berzin, P. Journal of Legal, Ethical and Regulatory Issues, 22(SI2), 1-6 (2019)

77. A. Kwilinski, K. Pajak, O. Halachenko, S. Vasylchak, Y. Pushak, P. Kuzior, Marketing and Management of Innovations, 4, 172-181 (2019)

78. A. Kwilinski, A. Kuzior, Management Systems in Production Engineering, 28(2), 119$123(2020)$

79. A. Kwilinski, Y. Zaloznova, N. Trushkina, N. Rynkevych, E3S Web of Conferences, 168, 00031 (2020)

80. A. Kwilinski, M. Dielini, O. Mazuryk, V. Filippov, V. Kitseliuk, Journal of Security and Sustainability Issues, 10(1), 345-358 (2020)

81. A. Kwilinski, D. Shteingauz, V. Maslov, Financial and Credit Activities: Problems of Theory and Practice, 3(34), 133-140 (2020)

82. A. Kwilinski, I. Slatvitskaya, T. Dugar, L. Khodakivska, B. Derevyanko, International Journal of Entrepreneurship, 24(1 Special Issue), 1-8 (2020)

83. A. Kwilinski, V. Litvin, E. Kamchatova, J. Polusmiak, D. Mironova, International Journal of Entrepreneurship, 25(1), 1-8 (2021)

84. Y. Kyrylov, V. Hranovska, V. Boiko, A. Kwilinski, L. Boiko, L. Journal of Risk and Financial Management, 13(12), 303 (2020)

85. V. Lakhno, V. Malyukov, T. Bochulia, Z. Hipters, A. Kwilinski, O. Tomashevska, International Journal of Civil Engineering and Technology, 9(8), 1802-1812 (2018)

86. O. Lyulyov, T. Pimonenko, A. Kwilinski, Y. Us, E3S Web of Conferences, 250, 03006 (2021)

87. K. Pająk, B. Kamińska, O. Kvilinskyi, O. Financial and Credit Activity: Problems of Theory and Practice, 2(21), 204-217 (2016)

88. T. Savchenko, N. Basiurkina, O. Rodina, A. Kwilinski, Management Theory and Studies for Rural Business and Infrastructure Development, 41(1), 43-61 (2019)

89. V. Tkachenko, A. Kwilinski, O. Korystin, N. Svyrydiuk, I. Tkachenko, Journal of Security and Sustainability, 8(3), 375-385 (2019)

90. V. Tkachenko, A. Kwilinski, M. Klymchuk, I. Tkachenko, Management Systems in Production Engineering, 27(2), 119-123 (2019)

91. V. Tkachenko, A. Kwilinski, I. Tkachenko, P. Puzyrova, Marketing and Management of Innovations, 2, 228-238 (2019)

92. V. Tkachenko, A. Kwilinski, B. Kaminska, I. Tkachenko, P. Puzyrova, Financial and Credit Activity: Problems of Theory and Practice, 3(30), 85-94 (2019)

93. V. Tkachenko, A. Kuzior, A. Kwilinski, Journal of Entrepreneurship Education, 22(6), 1-10 (2019)

94. L.M. Karpenko, M. Serbov, A. Kwilinski, V. Makedon, S. Drobyazko, Academy of Strategic Management Journal, 17(5), 1-7 (2018)

95. M. Borychowski, S. Stępień, J. Polcyn, A. Tošović-Stevanović, D. Ćalović, G. Lalić, M. Žuža, Sustainability, 12(24), 10362 (2020)

96. B. Czyżewski, A. Matuszczak, J. Polcyn, K. Smędzik-Ambroży, J. Staniszewski, Journal of Cleaner Production, 260, 121064 (2020)

97. J. Polcyn, Management, 22(2), 171-186 (2018)

98. J. Polcyn, Sustainability, 13(15), 6846 (2021)

99. A. Zielińska-Chmielewska, A. Olszańska, J. Kaźmierczyk, E.V. Andrianova, Agronomy, 11(2), 299 (2021)

100. R. Abazov, Herald of Journalism, 58(4), 34-43 (2021)

101. Y. Us, T. Pimonenko, O. Lyulyov. Polityka Energetyczna, 23(4), 49-66 (2021). doi:10.33223/epj/127397 
102. O. Chygryn, O. Lyulyov, T. Pimonenko, S. Mlaabdal. Engineering Management in Production and Services, 12(4), 92-104 (2020). doi:10.2478/emj-2020-0030

103. A. Rosokhata, O. Rybina, A. Derykolenko, V. Makerska. Research in World Economy, $11(4), 42-52$ (2020).

104. A. Rosokhata, M. Minchenko, L. Khomenko, O. Chygryn. Paper presented at the E3S Web of Conferences, , 250 (2021). doi:10.1051/e3sconf/202125003002

105. O. Chygryn, A. Rosokhata, O. Rybina, N. \& Stoyanets. Green competitiveness: The evolution of concept formation. Paper presented at the E3S Web of Conferences, 234 (2021). doi:10.1051/e3sconf/202123400004

106. K. Pająk, O. Kvilinskyi, O. Fasiecka, R. Miskiewicz, Economics and Environment, 2(61), 122-138 (2017)

107. J. Klein, N. Dawar. International Journal of Research in Marketing, 21(3), 203-217 (2004).

108. A.R. Andreasen. Journal of Public Policy and Marketing, 21(1), 3-13 (2002).

109. M. Geuens, B. Weijters, K. De Wulf. International Journal of Research in Marketing, 26(2), 97-107 (2009).

110. M. Greenberg. Branding new york: How a city in crisis was sold to the world. Branding new york: How a city in crisis was sold to the world, 1-326 (2008).

111. P. Sharma. Journal of International Business Studies, 42(2), 285-306 (2011).

112. H. He, Y. Li. Journal of Business Ethics, 100(4), 673-688(2011).

113. A. Williams. International Journal of Contemporary Hospitality Management, 18(6), 482-495 (2006).

114. G. van Noort, L. M. Willemsen. Journal of Interactive Marketing, 26(3), 131-140 (2012).

115. R. Kayaman, H. Arasli. Managing Service Quality, 17(1), 92-109 (2007).

116. R. W. Pollay, S. Siddarth, M. Siegel, A. Haddix, R. K. Merritt, G. A. Giovino, M. P. Eriksen. Journal of Marketing, 60(2), 1-16 (1996). 